University of Nebraska - Lincoln

DigitalCommons@University of Nebraska - Lincoln

Agronomy \& Horticulture - Faculty Publications

Agronomy and Horticulture Department

2006

\title{
Chemical composition and response to dilute-acid pretreatment and enzymatic saccharification of alfalfa, reed canarygrass, and switchgrass
}

\author{
Bruce S. Dien \\ USDA-ARS National Center for Agricultural Utilization Research, Bruce.Dien@ars.usda.gov \\ Hans-Joachim G. Jung \\ USDA-ARS \\ Kenneth P. Vogel \\ University of Nebraska-Lincoln, kvogel1@unl.edu \\ Michael D. Casler \\ USDA-ARS, michael.casler@ars.usda.gov \\ JoAnn F. S. Lamb \\ Plant Science Research Unit \\ Follow this and additional works at: https://digitalcommons.unl.edu/agronomyfacpub \\ ? next page for additional authors \\ Part of the Agricultural Science Commons, Agriculture Commons, Agronomy and Crop Sciences \\ Commons, Botany Commons, Horticulture Commons, Other Plant Sciences Commons, and the Plant \\ Biology Commons
}

Dien, Bruce S.; Jung, Hans-Joachim G.; Vogel, Kenneth P.; Casler, Michael D.; Lamb, JoAnn F. S.; Iten, Loren; Mitchell, Robert C.; and Sarath, Gautum, "Chemical composition and response to dilute-acid pretreatment and enzymatic saccharification of alfalfa, reed canarygrass, and switchgrass" (2006). Agronomy \& Horticulture -- Faculty Publications. 1032.

https://digitalcommons.unl.edu/agronomyfacpub/1032

This Article is brought to you for free and open access by the Agronomy and Horticulture Department at DigitalCommons@University of Nebraska - Lincoln. It has been accepted for inclusion in Agronomy \& Horticulture -Faculty Publications by an authorized administrator of DigitalCommons@University of Nebraska - Lincoln. 


\section{Authors}

Bruce S. Dien, Hans-Joachim G. Jung, Kenneth P. Vogel, Michael D. Casler, JoAnn F. S. Lamb, Loren Iten, Robert C. Mitchell, and Gautum Sarath 


\title{
Chemical composition and response to dilute-acid pretreatment and enzymatic saccharification of alfalfa, reed canarygrass, and switchgrass
}

\author{
Bruce S. Dien ${ }^{\mathrm{a}, *}$, Hans-Joachim G. Jung ${ }^{\mathrm{b}}$, Kenneth P. Vogel ${ }^{\mathrm{c}}$, Michael D. Casler ${ }^{\mathrm{d}}$, \\ JoAnn F.S. Lamb ${ }^{\mathrm{b}}$, Loren Iten ${ }^{\mathrm{a}}$, Robert B. Mitchell ${ }^{\mathrm{c}}$, Gautum Sarath \\ ${ }^{a}$ Fermentation Biotechnology Research Unit, National Center for Agricultural Utilization Research, USDA ${ }^{I}$, \\ Agricultural Research Service, 1815 N. University Street, Peoria, IL 61604, USA \\ ${ }^{\mathrm{b}}$ Plant Science Research Unit, 411 Borlaug Hall, 1991 Upper Buford Circle, St. Paul, MN 55108-6026, USA \\ ${ }^{\mathrm{c}}$ Wheat, Sorghum, and Forage Research Unit, 344 Keim Hall, University of Nebraska, Box 830937, Lincoln, NE 68583-0937, USA \\ ${ }^{\mathrm{d}}$ U.S. Dairy Forage Research Center, 1925 Linden Dr. West, Madison, WI 53706-1108, USA
}

Received 24 June 2005; received in revised form 22 February 2006; accepted 23 February 2006

Available online 2 May 2006

\begin{abstract}
Alfalfa stems, reed canarygrass, and switchgrass; perennial herbaceous species that have potential as biomass energy crops in temperate regions; were evaluated for their bioconversion potential as energy crops. Each forage species was harvested at two or three maturity stages and analyzed for carbohydrates, lignin, protein, lipid, organic acids, and mineral composition. The biomass samples were also evaluated for sugar yields following pretreatment with dilute sulfuric followed by enzymatic saccharification using a commercial cellulase preparation. Total carbohydrate content of the plants varied from 518 to $655 \mathrm{~g} \mathrm{~kg}^{-1}$ dry matter (DM) and cellulose concentration from 209 to $322 \mathrm{~g} \mathrm{~kg}^{-1}$ DM. Carbohydrate and lignin contents were lower for samples from early maturity samples compared to samples from late maturity harvests. Several important trends were observed in regards to the efficiency of sugar recovery following treatments with dilute acid and cellulase. First, a significant amount of the available carbohydrates were in the form of soluble sugars and storage carbohydrates $(4.3-16.3 \% \mathrm{wt} / \mathrm{wt})$. Recovery of soluble sugars following dilute acid pretreatment was problematic, especially that of fructose. Fructose was found to be extremely labile to the dilute acid pretreatments. Second, the efficiency at which available glucose was recovered was inversely correlated to maturity and lignin content. However, total glucose yields were higher for the later maturities because of higher cellulose contents compared to the earlier maturity samples. Finally, cell wall polysaccharides, as determined by the widely applied detergent fiber system were found to be inaccurate. The detergent fiber method consistently overestimated cellulose and hemicellulose and underestimated lignin by substantial amounts.
\end{abstract}

Published by Elsevier Ltd.

Keywords: Medicago sativa L.; Phalaris arundinacea L.; Panicum virgatum L.; Bioethanol; Biomass; Bioenergy

\section{Introduction}

Biomass can be converted into energy by thermochemical processes, including combustion, pyrolysis, and gasification [1], or by fermentation of carbohydrates to produce methane and ethanol $[1,2]$. Sources of lignocellu-

\footnotetext{
*Corresponding author. Tel.: + 13096816270 ; fax: + 13096816427.

E-mail address:dienb@ncaur.usda.gov (B.S. Dien).

${ }^{1}$ Mention of trade names or commercial products in this article is solely for the purpose of providing specific information and does not imply recommendation or endorsement by the US Department of Agriculture.
}

losic biomass include wood, paper waste, crop residues, and herbaceous energy crops. Perennial herbaceous energy crops have much to recommend them as a feedstock because once established they do not require annual reseeding, they require lower energy inputs (i.e., fertilizer and pesticides) than annual crops, and they can often be grown on more marginal cropland [3-5]. They also have environmental benefits including reduced soil erosion, enhanced carbon sequestration, and providing wildlife habitat [4,6-9]. Both the US and EU have supported research on herbaceous energy crops since the mid-1980s. Thirty-five herbaceous perennial species were screened by the US 
Department of Energy and switchgrass (Panicum virgatum L.) was selected for intensive study $[10,11]$. The EU investigated 20 perennial grasses and selected 4 as the most promising: miscanthus (Miscanthus spp. Anderss.), reed canarygrass (Phalaris arundinacea L.), giant reed (Arundo donax L.), and switchgrass [12]. Alfalfa (Medicago sativa L.) has also been considered for use as an energy crop in the US [13].

Three forage crops were selected for this study: alfalfa (only stems), reed canarygrass, and switchgrass. Selection of the three forage crops evaluated in this study was based upon high yield potential and other agronomic considerations. All of these species are broadly adapted to a range of environmental regions, but each species is also uniquely suited to special situations. For example, reed canarygrass is a cool-season grass that is very tolerant of flooding and its productivity is very responsive to high levels of nitrogen fertilization, making it a useful crop for disposal of manure from livestock operations [14]. In contrast, switchgrass is a warm-season grass that requires higher growth temperatures for maximum productivity, but this species is extremely drought tolerant and productive with minimal fertilizer inputs [10]. Alfalfa's unique traits include the fact that this legume does not need nitrogen fertilizer and the leaves are a valuable supplemental protein feed for livestock, providing another revenue stream from the use of this species as a biomass crop [15]. Of the three forage species evaluated in the current study, alfalfa may be best suited for use on land suitable for row cropping because alfalfa's productivity declines after 3-5 years and alfalfa can provide the majority of the nitrogen fertilizer requirements for 2 years of maize (Zea mays L.) production after the alfalfa stand is plowed down. Switchgrass and reed canarygrass remain productive for longer periods of time and are more suited to marginal cropland because these perennial grasses are more effective at controlling erosion and nutrient leaching. Clearly, choice of biomass crops must include their applicability to farming systems and characteristics of the land base available.

The efficiency of conversion of biomass to ethanol depends upon feedstock characteristics and composition, pretreatment processes, and the fermentation technologies that are utilized $[1,2,16]$. Feedstock quality for herbaceous energy crops has been extensively studied for use as livestock feed but not for ethanol conversion. Legumes, grasses with the $\mathrm{C}_{3}$ photosynthesis system, and grasses with the $\mathrm{C}_{4}$ photosynthesis system differ in plant anatomical characteristics which affect their chemical composition and utilization by ruminant animals [17]. Other important factors that are known to strongly impact chemical composition and digestion by ruminant animals include forage genotype, maturity, and growth environment, as well as, interaction among these factors [18]. This study focused on the influence of plant-type and maturity. The forages selected for this study include a legume (alfalfa), $\mathrm{C}_{3}$ grass (reed canarygrass), and $\mathrm{C}_{4}$ grass (switchgrass) each of which was harvested at two or three maturities. Biomass samples were characterized for total chemical composition, including carbohydrates, protein, lipids, Klason lignin, ash, etc. Next, recoverable sugar yields were evaluated by measuring monosaccharides released from the cell-wall matrix following treatment with dilute sulfuric-acid (at 121 and $150^{\circ} \mathrm{C}$ ) and enzymatic saccharification with a commercial cellulase. Finally, the compositional and yield data were combined to calculate the relative amount of recoverable sugars for each sample. The results showed clear distinctions among the samples based upon both plant-type and harvest maturity.

\section{Materials and methods}

\subsection{Plant material}

Herbaceous biomass crop samples were grown and harvested in 2003. The two alfalfa samples were created by harvesting and bulking numerous individual plants from several genetic nurseries at Rosemount and Becker, MN. These nurseries were established in 2001 and consisted of mature plants derived from intercrossing commercial alfalfa varieties. The reed canarygrass plant material was derived from a low-alkaloid population selected for improved establishment capacity that was planted at Arlington, WI. Switchgrass samples were collected from an established stand of the variety Cave-in-Rock located at Mead, NE. All field plots were fertilized for high productivity under local soil conditions. Plant materials were harvested at a $10 \mathrm{~cm}$ stubble height. The specific maturity stages and morphological description of the samples are detailed in Table 1. Following harvest, the biomass was air dried on greenhouse benches (switchgrass) or in forced-air ovens at $60^{\circ} \mathrm{C}$ (alfalfa and reed canarygrass). The dried

Table 1

Description of biomass samples used for pretreatment experiments

\begin{tabular}{ll}
\hline Species Maturity $^{\mathrm{a}}$ & Sample description \\
\hline $\begin{array}{l}\text { Alfalfa (Medicago sativa } \text { L.) } \\
\text { Bud (KF3) }\end{array}$ & $\begin{array}{l}\text { Stems, flower buds } \\
\text { present, no open flowers } \\
\text { Stems, open flowers on all } \\
\text { stem shoots }\end{array}$ \\
Full flower (KF6) & $\begin{array}{l}\text { Leaf blades and sheaths, } \\
\text { no stem elongation }\end{array}$ \\
Reed canarygrass (Phalaris arundinacea L.) & Whole herbage, ripe seed \\
Vegetative (V3) & $\begin{array}{l}\text { Leaf blades and sheaths, } \\
\text { elongated stems }\end{array}$ \\
Ripe seed (S5) & $\begin{array}{l}\text { Whole herbage, flower } \\
\text { panicle on stems open } \\
\text { Whitchgrass (Panicum virgatum } \text { L.) }\end{array}$ \\
Pre-boot (E3) & senescent, post-frost \\
Anthesis (R4) & serbage, ripe seed, \\
Post-frost (S5+) &
\end{tabular}

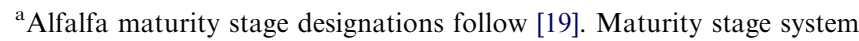
for grasses is based on [20]. 
alfalfa was hand separated into leaf and stem components. Total sample sizes were $\sim 12 \mathrm{~kg}$ for each of the alfalfa stem and reed canarygrass herbage harvests and $\sim 100 \mathrm{~kg}$ for the switchgrass herbage harvests. The switchgrass herbage and alfalfa stem samples were ground through a $2-\mathrm{mm}$ screen in a Wiley mill. The reed canarygrass samples were ground using a $1-\mathrm{mm}$ screen in a Wiley mill. Biomass samples were subsequently re-ground in a cyclone-type mill to pass a 1-mm screen for the compositional analyses, but not for the conversion experiments.

\subsection{Compositional analysis}

A complete compositional analysis was done for the biomass samples. Nitrogen content was determined by combustion, and crude protein concentration was estimated as $\mathrm{N} \times 6.25$ [21]. Lipid content was determined by exhaustive extraction with diethyl ether [22]. Organic acids were extracted with water and analyzed by HPLC with a refractive index detector [23]. Total ash content was measured as loss of weight after combustion at $450{ }^{\circ} \mathrm{C}$ for $16 \mathrm{~h}$ in a muffle furnace. Major mineral components in the biomass samples were determined using procedures described by Knudsen et al. [24].

Carbohydrates and lignin were determined using a sequential procedure. Soluble carbohydrates were extracted with $80 \% \mathrm{vol} / \mathrm{vol}$ ethanol at $60^{\circ} \mathrm{C}$ overnight [25]. The supernatant was analyzed by HPLC for monosaccharides (glucose and fructose) and oligosaccharides (sucrose, stachyose, and raffinose). The alcohol-insoluble residues were extracted with water at $4{ }^{\circ} \mathrm{C}$ overnight to remove fructans [25]. Fructans in the water-extract supernatant were determined using the ketose assay of Boratynski [26]. The water-insoluble residue was treated with heat-stable $\alpha$ amylase and amyloglucosidase in $0.1 \mathrm{M}$ acetate buffer, $\mathrm{pH}$ 5 , to release glucose from starch [27]. Sufficient 95\% $\mathrm{vol} / \mathrm{vol}$ ethanol was added to reach an alcohol concentration of $80 \%$, after which the supernatant was removed and analyzed by HPLC for glucose released from starch. The remaining crude, alcohol-insoluble cell wall residue was subjected to a two-stage sulfuric acid hydrolysis using the Uppsala Total Dietary Fiber Method [27]. An aliquot from the first stage of the acid hydrolysis was analyzed for uronic acids [28], using galacturonic acid as the reference standard for alfalfa and glucuronic acid as the standard for the two grasses. Neutral sugars from the two-stage acid hydrolysis were analyzed as alditol-acetate derivatives by GC-FID. The acid-insoluble residue provided the Klason lignin concentration estimate after correction for ash.

The biomass samples were also analyzed for cellulose, hemicellulose, and lignin using the detergent fiber system [29]. Neutral detergent fiber (NDF), acid detergent fiber (ADL), and acid detergent lignin (ADL) were determined sequentially using the Ankom (Ankom Technology Corporation, Fairport, NY) Filter Bag method [30]. Cellulose content was calculated as ADF minus ADL and hemicellulose as the difference between NDF and ADF values.
Gross energy content of the biomass samples was determined by bomb calorimetry using benzoic acid as the standard.

\subsection{Dilute acid pretreatment}

Two dilute-acid pretreatment methods were evaluated; $121^{\circ} \mathrm{C}$ in an autoclave and $150^{\circ} \mathrm{C}$ in a pipe reactor. Plant samples $(2 \mathrm{~g})$ were mixed with $18 \mathrm{ml}$ dilute sulfuric acid solution $(0-2.5 \% \mathrm{wt} / \mathrm{vol})$ in a glass vial capped with a screw cap lid and heated for $1 \mathrm{~h}$ in an autoclave set at $121^{\circ} \mathrm{C}$; the autoclave vented within $10 \mathrm{~min}$ following the end of the cycle. Alternately, plant samples were pretreated using steel pipe reactors and a fluidized heating sand bath as previously described [31]. Each plant sample $(2 \mathrm{~g})$ was mixed with $18 \mathrm{ml}$ of a dilute sulfuric acid solution in a pipe reactor. The samples were heated to $150^{\circ} \mathrm{C}$, incubated for $20 \mathrm{~min}$, and rapidly cooled by plunging the reactor in a cold-water bath; the time required to heat the samples was approximately $10 \mathrm{~min}$. The syrups resulting from the two dilute-acid pretreatments were subsampled and analyzed for monomeric and total soluble carbohydrates. The remaining syrup and solid pretreatment residues were enzymatically hydrolyzed.

\subsection{Enzymatic hydrolysis}

A modified version of the NREL Laboratory analytical procedure 9 was used to determine cellulose digestibility [32]. Acid-pretreated samples were diluted with $10 \mathrm{ml}$ water, neutralized with $4 \mathrm{M} \mathrm{KOH}$ to $\mathrm{pH} 4.5$, and buffered by adding $2.5 \mathrm{ml}$ of $1 \mathrm{M}$ citric acid ( $\mathrm{pH} 4.8$ ). The contents were transferred to a $125 \mathrm{ml}$ Erlenmeyer flask using two $7.5 \mathrm{ml}$ washes with water to insure complete transfer of solids. Cellulase $(1 \mathrm{ml})$ and thymol $\left(40 \mu \mathrm{l}\right.$ of a $50 \mathrm{~g} 1^{-1}$ solution in $70 \% \mathrm{vol} / \mathrm{vol}$ ethanol) were added and the contents incubated for $72 \mathrm{~h}$ in a shaker incubator set at $45^{\circ} \mathrm{C}$ and $125 \mathrm{rpm}$. The cellulase preparation used was an equal volume mixture of Celluclast 1.51 and $188 \beta$-glucosidase (Novozyme, Denmark). The cellulase mixture had an activity of 50 filter paper units $\mathrm{ml}^{-1}$, as measured by the previously described procedure of Ghose [33]. Incubation supernatants were analyzed for soluble carbohydrates.

\subsection{Measurement of released sugars}

Total soluble carbohydrates were analyzed by HPLC, after being hydrolyzed by treating with $2 \mathrm{M}$ TFA for $60 \mathrm{~min}$ at $100^{\circ} \mathrm{C}$ [34]. Samples were analyzed for sugars and acetic acid using a HPLC equipped with an organic acids column (Bio-Rad Laboratories, CA) and a refractive index detector, as previously described [31].

\subsection{Statistical analysis}

All compositional analyses were done in triplicate, and data were corrected to a $100 \%$ dry matter (DM) basis. 
Because there was only a single sample of each biomass species for every individual maturity stage, statistical analysis of the compositional data was not possible. Each biomass forage samples were subjected to 121 and $150^{\circ} \mathrm{C}$ dilute-acid pretreatments, and enzymatic hydrolysis, in triplicate. All of the maturity stage samples for each individual forage species were subjected to pretreatment as a group, but all seven biomass samples were not run concurrently. An analysis of variance was conducted on the pretreatment data using a completely randomized design with two factors (biomass sample and pretreatment method). Biomass sample was considered random and pretreatment method was considered fixed. Response to pretreatment could not be statistically compared among the seven biomass samples because all seven samples were not pretreated simultaneously. The overall effect of pretreatment method was tested using the mean squares for the interaction term. The interaction of biomass sample and pretreatment method was tested using the residual mean squares. Comparisons between the two pretreatment methods for individual biomass samples were done using the least-significant difference test if the interaction parameter was significant in the analysis of variance $(P<0.05)$. In the presentation of results, statistically significant $(P<0.05)$ differences are indicated as such. Pearson and Spearman correlation coefficients were determined among the response traits for dilute-acid pretreatment and with the composition of the biomass samples.

\section{Results}

\subsection{Biomass composition}

As expected, each of the three biomass species had unique compositional characteristics, but there were also important similarities among the species. Alfalfa $\left(\mathrm{C}_{3}\right.$ legume) stems had the highest concentrations of crude protein and organic acids of the three biomass species whereas reed canarygrass $\left(\mathrm{C}_{3}\right.$ grass $)$ had more etherextractable lipids and ash, and less Klason lignin, than the other two species (Table 2). Switchgrass $\left(\mathrm{C}_{4}\right.$ grass) was notable for having the lowest protein and organic acid concentrations, but the highest level of total carbohydrates. Concentrations of protein, ash, and organic acids declined with maturity for all three species while Klason lignin and total carbohydrate concentrations were higher in more mature biomass samples (Table 2). Total recovery of DM by the compositional analyses used was high for alfalfa stem samples $\left(\sim 960 \mathrm{~g} \mathrm{~kg}^{-1} \mathrm{DM}\right)$, but lower for the grass samples (889-917 $\left.\mathrm{g} \mathrm{kg}^{-1} \mathrm{DM}\right)$. Gross energy contents of all the alfalfa stem and switchgrass samples were very similar while reed canarygrass samples were lower (Table 2). Maturity of the biomass samples did not impact gross energy content appreciably.

Composition of the total carbohydrates in terms of soluble, storage, and cell wall fractions differed among biomass samples (Table 3). Sucrose was the predominant form of soluble carbohydrate in all the forage samples. There was a general trend toward reduced levels of sucrose with later maturity, with the exception that the anthesis stage sample for switchgrass had elevated sucrose levels compared to both older and younger switchgrass samples. Alfalfa stems generally had greater concentrations of glucose and lower concentrations of fructose than the two grasses. Switchgrass had more glucose and fructose in the anthesis sample than the other two switchgrass samples, with approximately equal amounts of each monosaccharide in a given sample. In contrast, alfalfa stems had virtually no fructose, and reed canarygrass had similar glucose and fructose concentrations at the vegetative stage but six times more fructose than glucose at the ripe seed stage. Only minor amounts of the oligosaccharides raffinose and stachyose were detected in the biomass samples. Starch was the storage carbohydrate form in alfalfa stems and switchgrass, with more starch in switchgrass especially at anthesis. Vegetative stage reed canarygrass contained $35 \mathrm{~g} \mathrm{~kg}^{-1} \mathrm{DM}$ fructans. The amount of

Table 2

Protein, lipid, ash, organic acids, lignin, carbohydrate, and gross energy content of bulk biomass forage samples

\begin{tabular}{|c|c|c|c|c|c|c|c|c|}
\hline Species $^{\mathrm{a}}$ Stage & $\begin{array}{l}\text { Crude } \\
\text { protein }(\mathrm{g} \\
\left.\mathrm{kg}^{-1} \mathrm{DM}\right)\end{array}$ & $\begin{array}{l}\text { Ether extract } \\
\left(\mathrm{g} \mathrm{kg}^{-1} \mathrm{DM}\right)\end{array}$ & $\begin{array}{l}\text { Ash (g } \\
\left.\mathrm{kg}^{-1} \mathrm{DM}\right)\end{array}$ & $\begin{array}{l}\text { Organic } \\
\text { acids }\left(\mathrm{g} \mathrm{kg}^{-1}\right. \\
\text { DM) }\end{array}$ & $\begin{array}{l}\text { Klason lignin } \\
\left(\mathrm{g} \mathrm{kg}^{-1} \mathrm{DM}\right)\end{array}$ & $\begin{array}{l}\text { Carbohydrates (g } \\
\mathrm{kg}^{-1} \mathrm{DM} \text { ) }\end{array}$ & $\begin{array}{l}\text { Total of } \\
\text { components } \\
\left(\mathrm{g} \mathrm{kg}^{-1} \mathrm{DM}\right)\end{array}$ & $\begin{array}{l}\text { Gross energy } \\
\text { values }(\mathrm{MJ} \\
\left.\mathrm{kg}^{-1}\right)\end{array}$ \\
\hline \multicolumn{9}{|l|}{ Alfalfa } \\
\hline Bud & 127 & 9 & 81 & 32 & 158 & 563 & 970 & 18.472 \\
\hline Full flower & 88 & 7 & 58 & 24 & 175 & 598 & 950 & 18.752 \\
\hline \multicolumn{9}{|c|}{ Reed canarygrass } \\
\hline Vegetative & 88 & 22 & 128 & 24 & 109 & 518 & 889 & 17.710 \\
\hline Ripe seed & 45 & 13 & 95 & 10 & 148 & 597 & 908 & 17.652 \\
\hline \multicolumn{9}{|l|}{ Switchgrass } \\
\hline Pre-boot & 65 & 10 & 89 & 9 & 133 & 569 & 875 & 18.221 \\
\hline Anthesis & 32 & 10 & 57 & 9 & 154 & 655 & 917 & 18.619 \\
\hline Post-frost & 30 & 16 & 57 & 3 & 173 & 650 & 915 & 18.694 \\
\hline
\end{tabular}

${ }^{\text {a }}$ Data are for alfalfa stems only; reed canarygrass and switchgrass data are for whole herbage. 


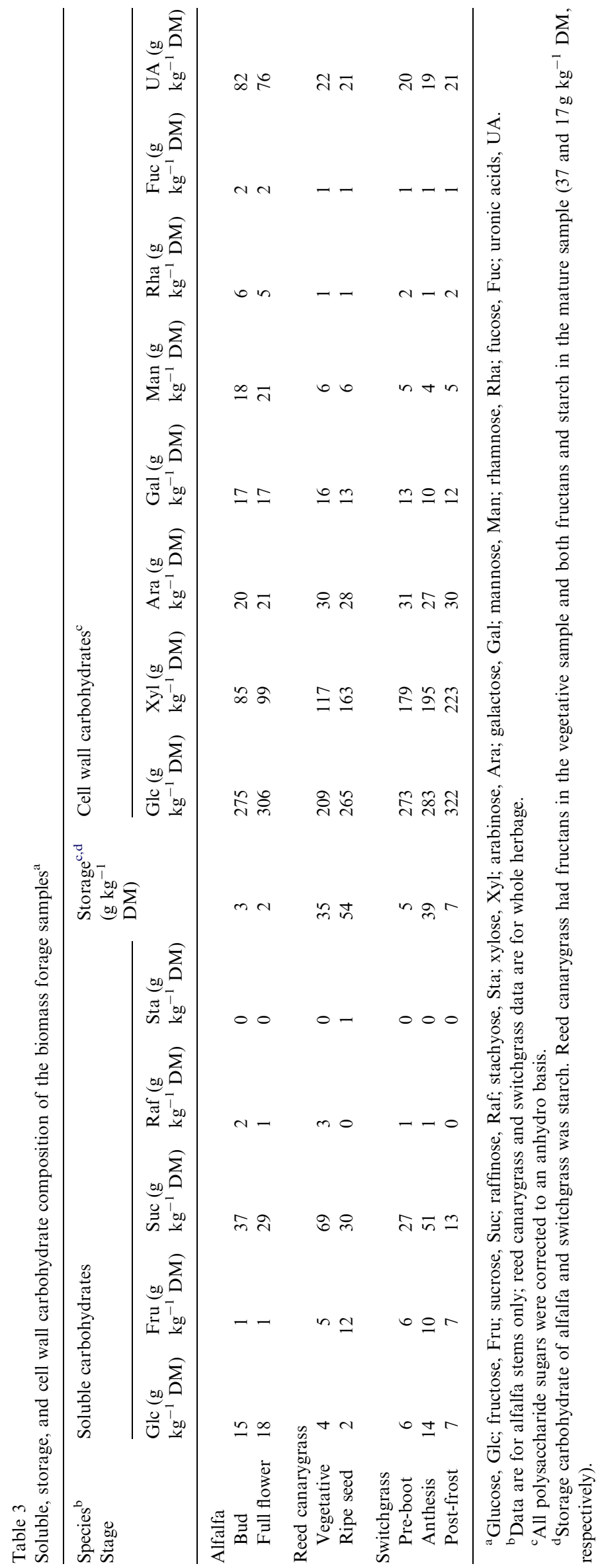

fructans was virtually the same for the ripe seed maturity stage of reed canarygrass, and this sample also contained $17 \mathrm{~g} \mathrm{~kg}^{-1} \mathrm{DM}$ of starch (Table 3). The total amount of non-cell wall carbohydrates in these forage samples present as soluble and storage carbohydrates ranged from $34 \mathrm{~g} \mathrm{~kg}^{-1} \mathrm{DM}$ for the post-frost switchgrass sample to $116 \mathrm{~g} \mathrm{~kg}^{-1} \mathrm{DM}$ in both of the least mature grass samples.

Glucose was the dominant monosaccharide residue in the cell wall polysaccharide fraction of all forage biomass samples, with xylose being the second most abundant polysaccharide component (Table 3 ). The ratio of glucose to xylose was approximately three-to-one for alfalfa stems, but was less than two-to-one for the grasses. Concentrations of both glucose and xylose increased with maturity for all three biomass species. Arabinose was the third most abundant monosaccharide residue in the grass samples, compared to uronic acids being of greater abundance in alfalfa stems. Among the more minor monosaccharide components, alfalfa had more mannose and rhamnose cell wall residues. Forage maturity had no obvious impact on minor monosaccharide composition of the cell wall material of any species.

Organic acids were a small proportion of the DM for all samples (Table 2). Malic acid was the predominant organic acid in all biomass samples and ranged from $14 \mathrm{~g} \mathrm{~kg}^{-1} \mathrm{DM}$ in bud stage alfalfa stems to $3 \mathrm{~g} \mathrm{~kg}^{-1} \mathrm{DM}$ in post-frost switchgrass. Malonic acid was most abundant in alfalfa stems $\left(11-14 \mathrm{~g} \mathrm{~kg}^{-1} \mathrm{DM}\right)$ and present in only trace amounts $\left(\leqslant 1 \mathrm{~g} \mathrm{~kg}^{-1} \mathrm{DM}\right)$ in switchgrass. Alfalfa stem samples were the only forage in which maleic acid was found $\left(3 \mathrm{~g} \mathrm{~kg}^{-1} \mathrm{DM}\right)$. None or trace amounts of citric, succinic, and fumaric acids were detected in these forage samples.

Elemental composition of the forage samples for the macro-minerals is shown in Table 4. The five grass samples contained much greater concentrations of $\mathrm{Si}$ than did the alfalfa stem samples. These high Si values indicate possible soil contamination of some samples. This was particularly true of the immature reed canarygrass sample that also contained high concentrations of $\mathrm{Mn}(257 \mathrm{ppm})$ and $\mathrm{Fe}$ $(554 \mathrm{ppm})$ compared to lower concentrations of $\mathrm{Mn}$ (13-80 ppm) and $\mathrm{Fe}(68-177 \mathrm{ppm})$ for the other forages. Of the other macro-minerals, $\mathrm{K}$ was present in the highest concentration for all biomass samples. There was a trend for $\mathrm{Cl}, \mathrm{K}$, and $\mathrm{S}$ concentrations to decline in more mature biomass samples. Phosphorus concentration was lower in the more mature alfalfa stem sample compared to the less mature alfalfa sample, whereas P levels increased for the more mature grass samples. Sodium concentrations were below detection limits of all the biomass samples except for the mature alfalfa stems and the immature reed canarygrass $\left(1.76\right.$ and $\left.2.36 \mathrm{~g} \mathrm{~kg}^{-1} \mathrm{DM}\right)$. Low concentrations $(<60 \mathrm{ppm})$ of the minor minerals $(\mathrm{Br}, \mathrm{Cr}, \mathrm{Cu}, \mathrm{Ni}, \mathrm{Rb}$, $\mathrm{Sr}, \mathrm{Ti}, \mathrm{Zr}$, and $\mathrm{Zn}$ ) were found in the biomass samples (data only reported in text). Concentrations of $\mathrm{Al}, \mathrm{As}, \mathrm{Ba}$, $\mathrm{Cd}, \mathrm{Co}, \mathrm{Cs}, \mathrm{Hg}, \mathrm{Mo}, \mathrm{Pb}, \mathrm{Se}$, and $\mathrm{V}$ were below detection limits. Because all the forages were not grown on the same 
Table 4

Macro-mineral composition of the biomass forage samples ${ }^{\mathrm{a}}$

\begin{tabular}{|c|c|c|c|c|c|c|c|}
\hline Species $^{\text {a }}$ Stage & $\mathrm{Ca}\left(\mathrm{g} \mathrm{kg}^{-1} \mathrm{DM}\right)$ & $\mathrm{Cl}\left(\mathrm{g} \mathrm{kg}^{-1} \mathrm{DM}\right)$ & $\begin{array}{l}\mathrm{Mg}\left(\mathrm{g} \mathrm{kg}^{-1}\right. \\
\mathrm{DM})\end{array}$ & $\mathrm{P}\left(\mathrm{g} \mathrm{kg}^{-1} \mathrm{DM}\right)$ & $\mathrm{K}\left(\mathrm{g} \mathrm{kg}^{-1} \mathrm{DM}\right)$ & $\mathrm{Si}\left(\mathrm{g} \mathrm{kg}^{-1} \mathrm{DM}\right)$ & $\mathrm{S}\left(\mathrm{g} \mathrm{kg}^{-1} \mathrm{DM}\right)$ \\
\hline \multicolumn{8}{|l|}{ Alfalfa } \\
\hline Bud & 6.87 & 5.14 & 3.09 & 3.19 & 29.42 & 1.42 & 1.64 \\
\hline Full flower & 7.61 & 4.12 & 1.87 & 1.83 & 21.11 & 1.17 & 0.65 \\
\hline \multicolumn{8}{|c|}{ Reed canarygrass } \\
\hline Vegetative & 8.13 & 8.56 & 3.18 & 2.12 & 19.24 & 91.39 & 2.78 \\
\hline Ripe seed & 4.66 & 6.13 & 2.92 & 2.47 & 18.42 & 90.74 & 1.85 \\
\hline \multicolumn{8}{|l|}{ Switchgrass } \\
\hline Pre-boot & 3.64 & 0.68 & 2.22 & 2.17 & 21.64 & 52.10 & 1.32 \\
\hline Anthesis & 2.80 & 0.21 & 1.62 & 3.43 & 10.20 & 34.57 & 0.63 \\
\hline Post-frost & 3.90 & 0.14 & 2.37 & 4.23 & 8.44 & 40.45 & 0.63 \\
\hline
\end{tabular}

${ }^{a}$ Data are for alfalfa stems only; reed canarygrass and switchgrass data are for whole herbage.

Table 5

Comparison of cell wall concentration and composition estimates for biomass forage samples derived from the Uppsala Dietary Fiber and detergent systems of analysis

\begin{tabular}{|c|c|c|c|c|c|c|c|c|}
\hline \multirow{2}{*}{$\begin{array}{l}\text { Species }^{\mathrm{a}} \\
\text { Stage }\end{array}$} & \multicolumn{2}{|l|}{ Cell wall } & \multicolumn{2}{|l|}{ Cellulose } & \multicolumn{2}{|l|}{ Hemicellulose } & \multicolumn{2}{|l|}{ Lignin } \\
\hline & $\begin{array}{l}\text { Dietary } \\
\text { Fiber }^{\mathrm{b}}\end{array}$ & $\begin{array}{l}\mathrm{NDF}^{\mathrm{c}} \\
\left(\mathrm{g} \mathrm{kg}^{-1} \mathrm{DM}\right)\end{array}$ & $\begin{array}{l}\text { Glucose } \\
\left(\mathrm{g} \mathrm{kg}^{-1} \mathrm{DM}\right)\end{array}$ & $\begin{array}{l}\text { ADF-ADL } \\
\left(\mathrm{g} \mathrm{kg}^{-1} \mathrm{DM}\right)\end{array}$ & $\begin{array}{l}\text { Sugars }^{\mathrm{d}} \\
\left(\mathrm{g} \mathrm{kg}^{-1} \mathrm{DM}\right)\end{array}$ & $\begin{array}{l}\text { NDF-ADF } \\
\left(\mathrm{g} \mathrm{kg}^{-1} \mathrm{DM}\right)\end{array}$ & $\begin{array}{l}\mathrm{KL}\left(\mathrm{g} \mathrm{kg}^{-1}\right. \\
\mathrm{DM})\end{array}$ & $\begin{array}{l}\text { ADL }\left(\mathrm{g} \mathrm{kg}^{-1}\right. \\
\mathrm{DM})\end{array}$ \\
\hline \multicolumn{9}{|l|}{ Alfalfa } \\
\hline Bud & 663 & 589 & 275 & 397 & 105 & 130 & 158 & 55 \\
\hline Full flower & 722 & 669 & 306 & 444 & 122 & 144 & 175 & 71 \\
\hline \multicolumn{9}{|c|}{ Reed canarygrass } \\
\hline Vegetative & 511 & 541 & 209 & 287 & 175 & 244 & 109 & 2 \\
\hline Ripe seed & 646 & 689 & 265 & 356 & 218 & 305 & 148 & 20 \\
\hline \multicolumn{9}{|l|}{ Switchgrass } \\
\hline Pre-boot & 657 & 669 & 273 & 337 & 235 & 318 & 133 & 12 \\
\hline Anthesis & 694 & 669 & 283 & 340 & 245 & 301 & 154 & 23 \\
\hline Post-frost & 789 & 733 & 322 & 383 & 279 & 311 & 173 & 34 \\
\hline
\end{tabular}

${ }^{a}$ Data are for alfalfa stems only; reed canarygrass and switchgrass data are for whole herbage.

${ }^{\mathrm{b}}$ Sum of neutral sugars, uronic acids, and Klason lignin from Uppsala dietary fiber analysis.

${ }^{\mathrm{c}}$ Neutral detergent fiber, NDF; acid detergent fiber, ADF; acid detergent lignin, ADL; from the detergent analysis system.

${ }^{\mathrm{d}}$ Hemicellulose concentration was based on the sum of xylose + mannose + fructose for alfalfa; and the sum of xylose + arabinose + mannose + uronic acids for the two grasses.

soils, comparisons among species for mineral composition are not reliable.

Estimates of cell wall, cellulose, hemicellulose, and lignin concentrations derived from the Uppsala Dietary Fiber and detergent fiber systems of analysis are presented in Table 5. Alfalfa stem cell wall concentration was consistently less when determined as NDF than as dietary fiber. For reed canarygrass the opposite pattern for NDF vs. dietary fiber was observed, although the differences between the estimates were smaller than for alfalfa stems. Dietary fiber analysis resulted in a somewhat lower estimate for cell wall concentration of pre-boot switchgrass than the NDF value, but dietary fiber analysis gave higher cell wall concentration estimates for the two later maturity stages of switchgrass, with the difference between analytical methods increasing with more advanced switchgrass maturity. For all biomass forage samples, cellulose and hemicellulose concentration estimates from detergent analysis were greater than using the dietary fiber method, whereas ADL provided extremely low lignin concentration estimates compared to Klason lignin.

\subsection{Optimizing pretreatment conditions}

The plant biomass samples were pretreated using diluteacid to prepare them for hydrolysis with cellulase. The biomass samples were treated as $10 \% \mathrm{wt} / \mathrm{vol}$ slurry and heated at $121{ }^{\circ} \mathrm{C}$ in an autoclave for $1 \mathrm{~h}$. The most immature sample for each forage species was used to optimize sulfuric acid loading for maximum non-glucose sugar and total glucose yields. The effect of acid loading on final $\mathrm{pH}$ is shown in Fig. 1. The two grasses showed similar $\mathrm{pH}$ profiles for the different acid loadings. The $\mathrm{pH}$ profile of the alfalfa sample was shifted $0.4-0.5 \mathrm{pH}$ units 


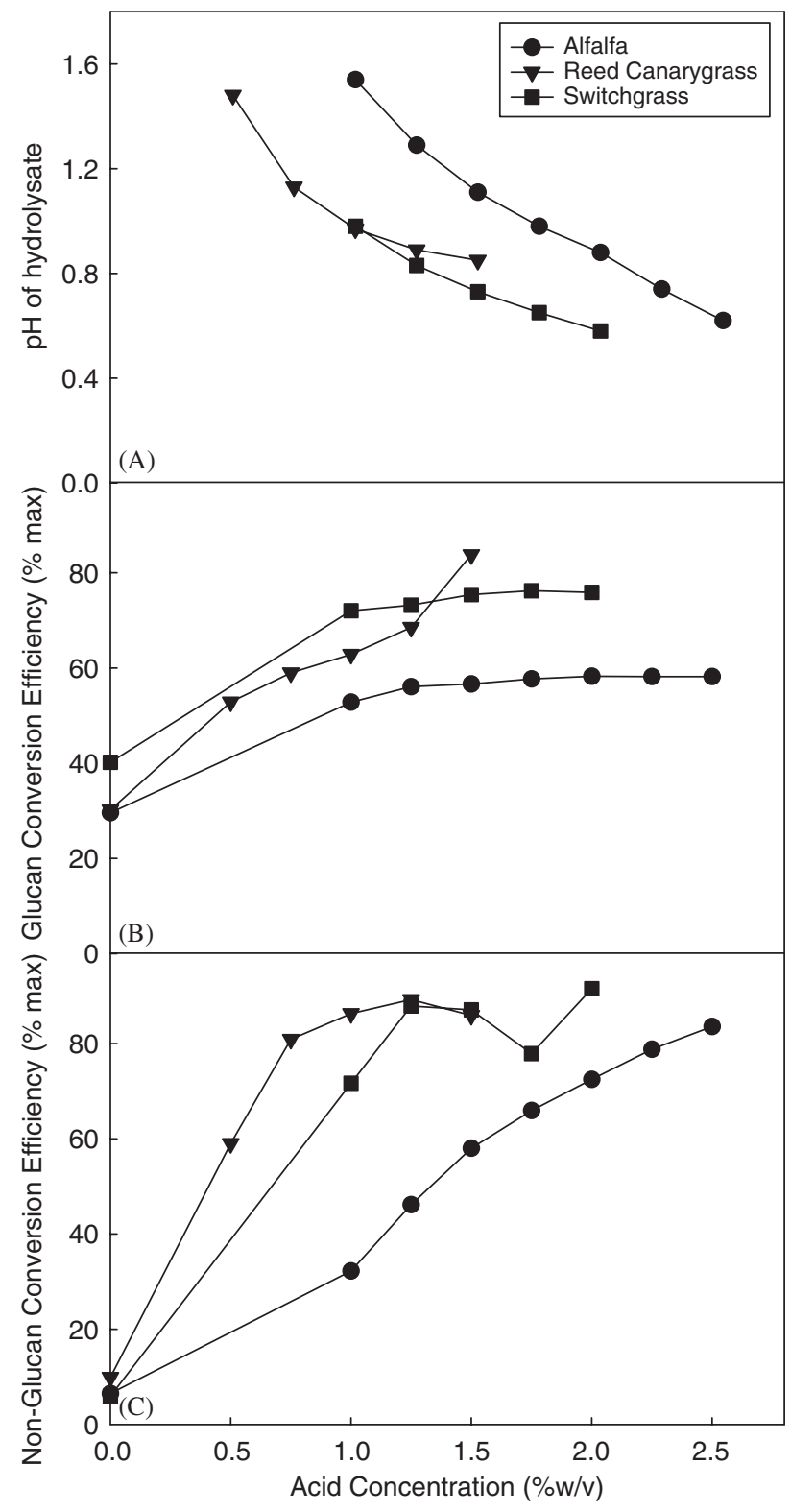

Fig. 1. Optimization of sulfuric acid loading for pretreating the most immature alfalfa $(\bullet)$, reed canarygrass $(\boldsymbol{\nabla})$, and switchgrass $(\mathbf{\square})$ biomass samples at $121^{\circ} \mathrm{C}$ for $1 \mathrm{~h}$. Final reaction mixture $\mathrm{pH}(\mathrm{A})$, and efficiencies of glucan (B) and non-glucan (C) recovery of monosaccharides for pretreated biomass samples.

higher than the grasses for similar acid loadings, indicating that this alfalfa stem sample had a higher buffering capacity.

The optimal acid loadings were set at those giving the maximum non-glucose sugar yield (arabinose, fructose, mannose, and xylose) and highest glucose yield following pretreatment and cellulase saccharification. The final sugar yields from treating each of the plant biomass samples at varying acid loadings followed by cellulase are shown in Figs. $1 \mathrm{~b}$ and c. Maximum sugar yields for the switchgrass and canarygrass appeared to plateau beginning at $1.25 \%$ $\mathrm{wt} / \mathrm{vol}$ acid. The alfalfa glucose yield leveled off at $1.25 \%$, but non-glucose yield continued increasing until $2.25 \%$. At $2.5 \%$ acid loading, the total yield of monosaccharides, excluding glucose, was $84 \%$. Therefore, the acid loadings were set at $1.5 \%$ for the grasses and $2.5 \%$ for alfalfa in subsequent experiments. At the optimal acid concentrations, non-glucose sugar yields were $84-92 \%$ of available carbohydrates. The recovery of glucose was lower for alfalfa $(58.2 \%$ of maximum) compared to the grasses (75.4-83.8\%).

\subsection{Sugar yields}

Recoveries of glucose and non-glucose sugars after dilute-acid pretreatment and enzymatic saccharification are shown in Table 6. Glucose yield from just the diluteacid pretreatment alone (and before treatment with cellulase) ranged from 44 to $112 \mathrm{~g} \mathrm{~kg}^{-1} \mathrm{DM}$ for the biomass forage samples. All of the biomass samples were relatively similar in their acid-released glucose yields with the exception of an approximately two-fold greater glucose yield from the anthesis stage switchgrass. Differences between the two dilute-acid pretreatment methods (121 vs. $150^{\circ} \mathrm{C}$ ) were only observed for three biomass samples, with the more mature alfalfa and reed canarygrass samples having higher $(P<0.05)$ glucose yields at 150 than $121^{\circ} \mathrm{C}$. In contrast, the anthesis stage switchgrass had a lower $(P<0.05)$ glucose yield after treatment at $150{ }^{\circ} \mathrm{C}$. Yield of non-glucose sugars from the dilute-acid pretreatments were depressed $(P<0.05)$ by the higher temperature pretreatment conditions for all biomass samples except the postfrost switchgrass (Table 6). The same pattern was observed for acetate release by dilute-acid pretreatment. While all biomass samples were similar in acetate yields, the alfalfa stem samples yielded less non-glucose sugars by dilute-acid pretreatment than observed for the grass samples.

Dilute-acid pretreatment at $150{ }^{\circ} \mathrm{C}$ resulted in higher $(P<0.05)$ glucose yields from enzymatic saccharification for all biomass samples except the immature reed canarygrass (Table 6). Because the bulk of the total glucose released by combined dilute-acid pretreatment followed by cellulase hydrolysis was derived from the cellulase step in the procedure, it was not unexpected that total glucose yield was also increased $(P<0.05)$ by the higher pretreatment temperature for all biomass samples except the immature reed canarygrass. Alfalfa stems and reed canarygrass herbage samples were similar in total glucose yield, but switchgrass tended to give greater total glucose yields.

Efficiency of glucose release by the combined dilute-acid pretreatment and enzymatic saccharification was greater $(P<0.05)$ for all biomass samples when pretreated at $150^{\circ} \mathrm{C}$ rather than $121^{\circ} \mathrm{C}$ (Fig. 2A). Exactly the opposite pattern was observed for efficiency of non-glucose recovery from the biomass samples (Fig. 2B). There was a clear trend for lower efficiencies of glucose recovery for more mature biomass samples compared to less mature samples within the three forage species. A similar trend was not 
Table 6

Yields of monosaccharides and acetate after pretreatment at 121 or $150^{\circ} \mathrm{C}$ and cellulase hydrolysis of biomass samples

\begin{tabular}{|c|c|c|c|c|c|c|}
\hline \multirow{2}{*}{$\begin{array}{l}\text { Species }^{\mathrm{a}} \\
\text { Maturity }\end{array}$} & \multirow{2}{*}{$\begin{array}{l}\text { Pretreatment } \\
\left({ }^{\circ} \mathrm{C}\right)\end{array}$} & \multicolumn{3}{|c|}{ Released by acid pretreatment } & \multirow{2}{*}{$\begin{array}{l}\text { Released by } \\
\text { cellulase }\left(\mathrm{g} \mathrm{kg}^{-1}\right. \\
\mathrm{DM})\end{array}$} & \multirow{2}{*}{$\begin{array}{l}\text { Total glucose } \\
\text { released }\left(\mathrm{g} \mathrm{kg}^{-1}\right. \\
\mathrm{DM})\end{array}$} \\
\hline & & $\begin{array}{l}\text { Glucose }\left(\mathrm{g} \mathrm{kg}^{-1}\right. \\
\text { DM) }\end{array}$ & $\begin{array}{l}\text { Non-glucose } \\
\left(\mathrm{g} \mathrm{kg}^{-1} \mathrm{DM}\right)\end{array}$ & $\begin{array}{l}\text { Acetate }\left(\mathrm{g} \mathrm{kg}^{-1}\right. \\
\text { DM) }\end{array}$ & & \\
\hline \multicolumn{7}{|l|}{ Alfalfa } \\
\hline \multirow[t]{2}{*}{ Bud } & 121 & 46 & $121 \mathrm{a}$ & $29 \mathrm{a}$ & $176 \mathrm{a}$ & $223 \mathrm{a}$ \\
\hline & 150 & 44 & $101 \mathrm{~b}$ & $18 \mathrm{~b}$ & $201 b$ & $245 b$ \\
\hline \multirow[t]{2}{*}{ Full flower } & 121 & $44 \mathrm{a}$ & $137 \mathrm{a}$ & $34 \mathrm{a}$ & $173 \mathrm{a}$ & $217 \mathrm{a}$ \\
\hline & 150 & $51 \mathrm{~b}$ & $123 b$ & $20 \mathrm{~b}$ & $187 \mathrm{~b}$ & $238 b$ \\
\hline \multicolumn{7}{|c|}{ Reed canarygrass } \\
\hline \multirow[t]{2}{*}{ Vegetative } & 121 & 58 & $250 \mathrm{a}$ & $13 \mathrm{a}$ & 168 & 226 \\
\hline & 150 & 60 & $179 \mathrm{~b}$ & $24 \mathrm{~b}$ & 179 & 239 \\
\hline \multirow[t]{2}{*}{ Ripe seed } & 121 & $49 \mathrm{a}$ & $261 \mathrm{a}$ & $20 \mathrm{a}$ & $151 \mathrm{a}$ & $200 \mathrm{a}$ \\
\hline & 150 & $53 b$ & $214 b$ & $24 \mathrm{~b}$ & $197 \mathrm{~b}$ & $250 \mathrm{~b}$ \\
\hline \multicolumn{7}{|l|}{ Switchgrass } \\
\hline \multirow[t]{2}{*}{ Pre-boot } & 121 & 52 & $238 \mathrm{a}$ & 19 & $191 \mathrm{a}$ & $243 \mathrm{a}$ \\
\hline & 150 & 55 & $223 b$ & 18 & $228 b$ & $283 b$ \\
\hline \multirow[t]{2}{*}{ Anthesis } & 121 & $112 \mathrm{a}$ & $243 a$ & $24 \mathrm{a}$ & $146 \mathrm{a}$ & $258 \mathrm{a}$ \\
\hline & 150 & $105 \mathrm{~b}$ & $206 \mathrm{~b}$ & $21 \mathrm{~b}$ & $207 \mathrm{~b}$ & $312 b$ \\
\hline \multirow[t]{2}{*}{ Post-frost } & 121 & 49 & 252 & 24 & $184 \mathrm{a}$ & $233 a$ \\
\hline & 150 & 50 & 241 & 24 & $228 b$ & $278 b$ \\
\hline SEM & & 1 & 4 & 1 & 5 & 5 \\
\hline
\end{tabular}

Means not sharing a common alphabet, within individual biomass samples, differ for response to the two pretreatment temperatures $(P<0.05)$.

${ }^{a}$ Data are for alfalfa stems only; reed canarygrass and switchgrass data are for whole herbage.

${ }^{\mathrm{b}}$ Does not include uronic acids.

evident for efficiency of non-glucose sugar recovery. The least mature grass samples stood out from the other biomass samples with greater glucose efficiency when pretreated at $121^{\circ} \mathrm{C}$, whereas the two alfalfa stem samples were lower in glucose recovery than all the grasses when pretreated at $150^{\circ} \mathrm{C}$.

Dilute-acid pretreatment at the higher temperature had an unfavorable effect on non-glucose sugar conversion efficiency and yield. On average, yields were $12 \%$ lower at the higher temperature. We suspected that this loss in yield could be accounted for by rapid degradation of fructose during dilute-acid pretreatment at elevated temperatures. The major source of fructose for most samples was sucrose, a glucose and fructose disaccharide; however, reed canarygrass also contained significant amounts of fructans (Table 2). To test this hypothesis, we treated $20 \mathrm{gl}^{-1}$ of sucrose under the same pretreatment conditions used for the grasses. The sucrose was converted to glucose and fructose prior to reaching $150{ }^{\circ} \mathrm{C}$, and the fructose was entirely degraded within the next $10 \mathrm{~min}$ (data not shown). To further investigate the influence of fructose on non-glucose yields, the difference in non-glucose sugar yields between the two dilute-acid pretreatment temperatures was plotted against the fructose content for each biomass sample. There was almost a onefor-one reduction in non-glucose sugar yield between the 121 and $150{ }^{\circ} \mathrm{C}$ pretreatment temperatures with fructose concentration across all the biomass samples $(r=0.97$, $P<0.001)$.

\subsection{Correlations between composition and pretreatment conditions}

Concentration of Klason lignin of the biomass samples was correlated with total and cell wall glucose concentrations of the samples $(r=0.94$ and 0.86 , respectively, $P<0.05)$. Klason lignin concentration was not correlated $(P>0.05)$ with non-glucose sugars. Concentrations of glucose and non-glucose sugars in the cell wall were negatively correlated $(r=-0.85, P<0.05)$, and each of these fractions was positively correlated with their respective total sugar concentration $(r=0.87$ and 0.85 for glucose and non-glucose, respectively, $P<0.05$ ).

The differences outlined above for sugar yields and recovery efficiencies between the two dilute-acid pretreatment temperatures were reflected in the correlations between these pretreatment temperatures for the response traits. Linear correlations between the two dilute-acid pretreatments were significant $(P<0.05)$ for acid-released glucose and non-glucose sugar yields, total glucose yield, and efficiency of glucose recovery $(r=0.83-0.99)$. Total glucose yield between the two dilute-acid pretreatment temperatures was similar $(r=0.84, P<0.05)$. Acid-released acetate and cellulase-released glucose yields, and efficiency of non-glucose sugar recovery were not correlated $(P>0.05)$ between the two pretreatment temperatures. Rank correlations of the two pretreatment temperatures were only significant for acid-released glucose yield $(r=0.86, P<0.05)$. 


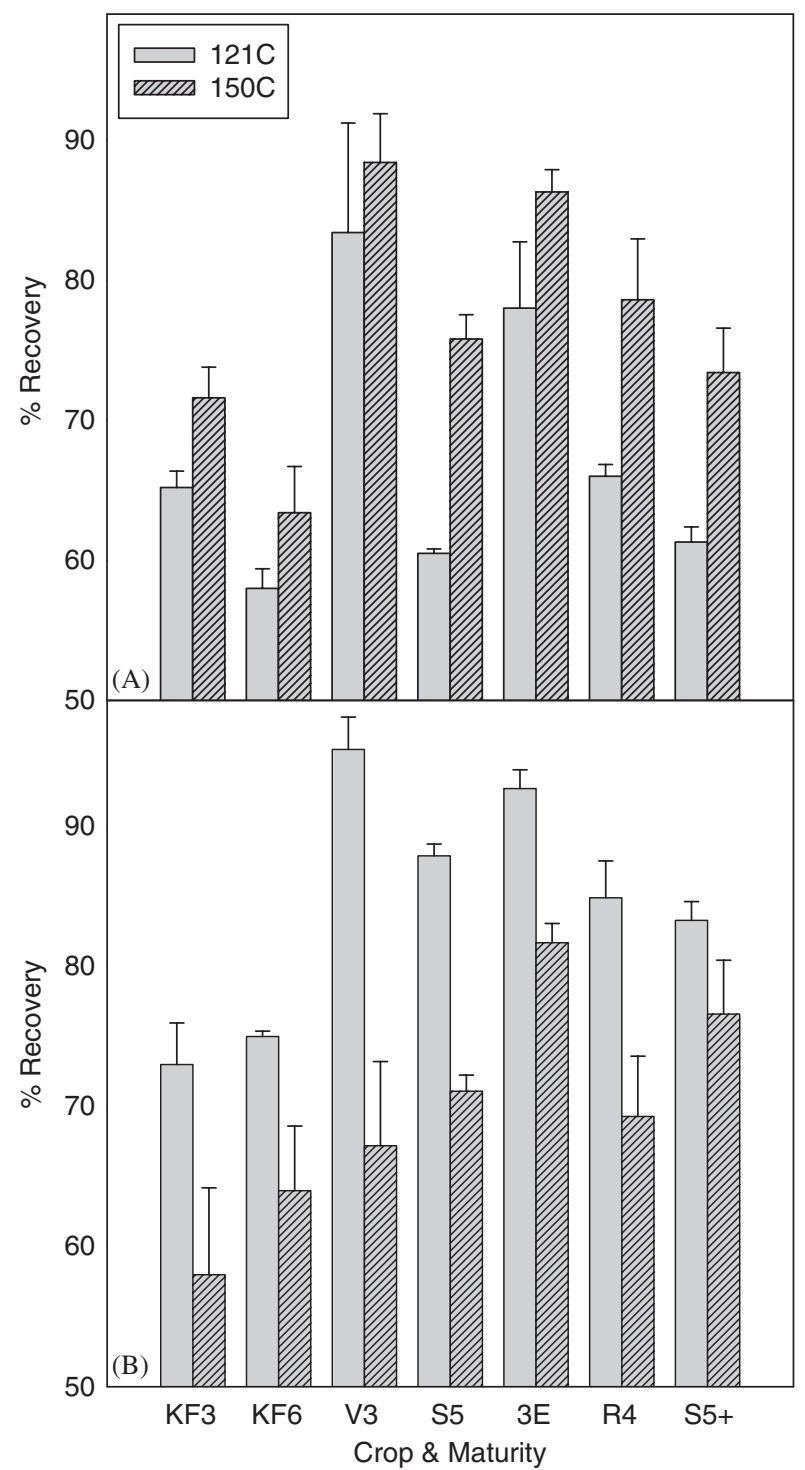

Fig. 2. Efficiency of glucose (A) and non-glucose (B) sugar recovery after pretreatment of immature and mature alfalfa, reed canarygrass, and switchgrass biomass samples at 121 and $150{ }^{\circ} \mathrm{C}$. Abbreviations: alfalfa bud (KF3), full flower, (KF6); reed canarygrass vegetative (V3), ripe seed (S5); switchgrass pre-boot (E3), anthesis (R4), and post frost (S5+). See Table 1 for explanation of maturities.

Within both of the dilute-acid pretreatments, acidreleased glucose yield was positively correlated with noncell wall glucose concentration $(r=0.92$ for both pretreatments, $P<0.01)$. Also, acid-released non-glucose yield was correlated with total non-glucose concentration of the biomass samples for both pretreatments $(r=0.96$ for both pretreatments, $P<0.001)$. Klason lignin concentration was negatively correlated with efficiency of glucose recovery for both pretreatments (Fig. 3). Beyond these consistent relationships for both dilute-acid pretreatments, different correlation patterns of composition with response to pretreatment conditions were observed. Glucose yield from the cellulase hydrolysis step was negatively correlated with non-cell wall glucose concentration $(r=-0.78, P<0.05)$

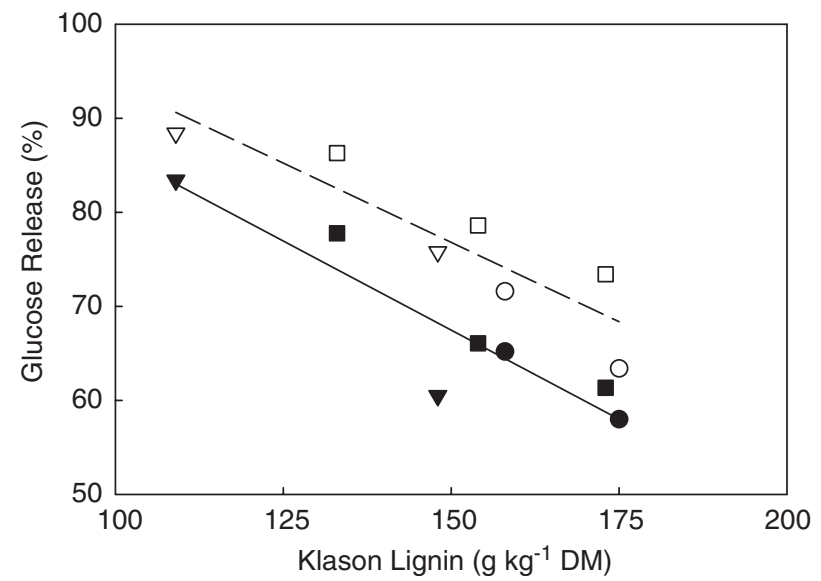

Fig. 3. Regressions for efficiency of glucose release with Klason lignin concentration as a proportion of dry matter $\left(r^{2}=0.85\right.$ and 0.82 for 121 and $150{ }^{\circ} \mathrm{C}$, respectively, $\left.P<0.01\right)$ for immature and mature alfalfa $(\bigcirc, \bullet)$, reed canarygrass $(\nabla, \nabla)$, and switchgrass $(\square, \mathbf{\square})$ biomass samples pretreated at $121{ }^{\circ} \mathrm{C}$ (closed symbols) and $150{ }^{\circ} \mathrm{C}$ (open symbols).

for the $121^{\circ} \mathrm{C}$ dilute acid pretreatment. Efficiency of glucose recovery was negatively correlated with both cell wall and total glucose concentrations $(r=-0.82$ and -0.78 , respectively, $P<0.05$ ), and efficiency of non-glucose sugar recovery was negatively correlated with total glucose concentration $(r=-0.76, P<0.05)$ for the $121{ }^{\circ} \mathrm{C}$ diluteacid pretreatment. In contrast, acid-released non-glucose sugar, cellulase-released glucose, and total glucose yields were all positively correlated with cell wall concentration of non-glucose sugars $(r=0.91,0.78$, and 0.77 , respectively, $P<0.05)$ when biomass samples were pretreated at $150^{\circ} \mathrm{C}$. Klason lignin concentration of the biomass samples was correlated with acid-released acetate yield and efficiency of non-glucose sugar recovery for the $121{ }^{\circ} \mathrm{C}$ pretreatment ( $r=0.87$ and -0.84 , respectively, $P<0.05$ ), but no additional correlations of Klason lignin concentration with other response traits were found.

\section{Discussion}

\subsection{Comparison of biomass samples}

Wide differences were detected for the three crops evaluated in this study. Switchgrass had more total carbohydrates on a weight basis than the other biomass crops examined, and both switchgrass and alfalfa had higher glucose concentrations than reed canarygrass. It should be noted that the composition of post frost switchgrass is similar to that reported in the DOE feedstock database (www1.eere.energy.gov/biomass/feedstock_databases.html). Larger amounts of glucose are advantageous for ethanol production because glucose can (currently) be converted at higher yields to ethanol than most other sugars, especially compared to pentoses [35], and glucose is fermented by industrial yeast strains. Harvesting more mature forage resulted in higher concentrations of cell wall glucose and non-glucose sugars. 
Unfortunately, lignin concentration also increased for the more mature samples. The negative relationship of Klason lignin concentration with efficiency of glucose recovery after dilute-acid pretreatment and enzymatic saccharification mimics the same negative impact of lignification on digestibility of forages by ruminants [36]. Because increasing pretreatment temperature improved glucose recovery, ethanol production systems will require optimization of biomass composition with cost of pretreatment.

A unique aspect of this study was that the non-cell wall carbohydrates present in these candidate biomass crops were characterized. These non-cell wall sugars accounted for $4.3-16.3 \%$ of the potentially fermentable carbohydrates in these biomass crops. Unlike cell wall polysaccharides, these non-cell wall carbohydrates are directly fermentable without harsh pretreatment. However, these non-cell wall carbohydrates are particularly susceptible to microbial degradation and Maillard-type reactions during harvesting and storage. As shown in the current study for fructose, some non-cell wall carbohydrates are also more sensitive to degradation during dilute-acid pretreatment. Therefore, the presence of significant non-cell wall carbohydrates may be an important consideration in selection and processing biomass feedstocks.

The biomass samples were analyzed by both the Uppsala Dietary Fiber system [27] and the detergent analysis system [29]. The later is the standard method employed for analyzing forage crops in feed quality analysis. As such, there is a wealth of detergent fiber information on forages and, just as importantly, rapid and inexpensive methods of analysis. While data obtained from detergent fiber method are good predictors of digestibility [37], we found the detergent fractions inaccurate for measuring actual cell wall composition. The detergent method consistently overestimated cellulose and hemicellulose and underestimated lignin by substantial amounts. The detergent method also suggested that alfalfa had twice the lignin content found in either grass, whereas the more accurate Klason lignin measurement [38] indicated the biomass samples had similar amounts of lignin. This is not the first time the accuracy of the detergent method has been questioned [39]. The inaccuracies associated with detergent fiber analysis include loss of pectic polysaccharides during neutral detergent extraction [39], incomplete removal of xylans with acid detergent extraction [40], and loss of lignin during the acid detergent step [38]. Predicting cell wall composition data from detergent fiber composition was unsuccessful for alfalfa stems [41]. Therefore, detergent fiber composition data are of little value in evaluating the carbohydrate and lignin content of biomass feedstocks.

\subsection{Recovery of glucose}

Total glucose yields were most influenced by maturity. For all the species treated at either 121 or $150{ }^{\circ} \mathrm{C}$, glucose conversion efficiency declined with greater maturity. Maturation in plants is accompanied by reduced non-cell wall carbohydrates and increased structural carbohydrates and lignin concentrations [42]. Both of these trends were observed in this study. Lignin has previously been observed to inhibit enzymatic cellulose degradability [43]. The same pattern of reduced efficiency of glucose recovery with elevated lignin concentration was observed in the current study. While the efficiency at which glucose was recovered decreased with maturity, glucose yields actually increased because the more mature biomass samples had higher cellulose concentrations. Based on our results, Klason lignin concentration can be used to predict efficiency of glucose recovery from herbaceous biomass in a dilute-acid/ cellulase conversion system. However, total yield of glucose in such a system cannot be predicted from lignin concentration alone. Glucose yield is a function of both lignin and glucose concentrations of the biomass sample. While the influence of crop maturity on forage digestibility by livestock has been demonstrated repeatedly [18], this is the first time biomass maturity has been shown to influence glucose recovery when biomass is pretreated with dilute-acid followed by cellulase.

Glucose conversion efficiencies were substantially greater for the immature grass samples than observed for the more mature grass and both alfalfa stem samples, reflecting lignin concentration of the samples. All biomass samples responded positively for efficiency of glucose recovery when pretreatment temperatures were increased from 121 to $150^{\circ} \mathrm{C}$, although the impact was greater for the more mature grass samples than alfalfa stems. It is not immediately apparent from the composition of these biomass samples why this differential response occurred, particularly for both alfalfa stem samples compared to the response for the grasses. It is known that cellulose conversion can be negatively impacted by inefficient removal of hemicellulose [43-45]. However, the alfalfa stem samples contained less hemicellulose than the grasses, and removal of hemicellulose was highly efficient for all the biomass samples in the current study. When Torget et al. $[46,47]$ evaluated cellulose degradability from several herbaceous annuals after pretreatment, they also observed that legume cellulose was more recalcitrant than grasses. Most likely the difference in degradability is related to differences in plant cell wall structures between the grasses and alfalfa. Lignin is much more uniformly distributed among tissues of grasses [17] than legumes [48]. One hypothesis, not pursued in this study, is that the more resistant cellulose in legumes is associated with those particular tissues containing elevated lignin concentrations.

Another important difference noticed between alfalfa stems and the grasses is that alfalfa had a greater buffering capacity. Acid loadings of $2.25 \%$ were required for the alfalfa stem samples to reach a final $\mathrm{pH}$ of $\sim 1.0$ compared to $1.5 \%$ acid for the grasses. Torget et al. [46] also observed that legumes had higher buffering capacities than grasses. The higher buffering capacity of legumes may be related to differences in composition. First, the alfalfa stem samples had higher protein concentrations than the grasses. 
Second, alfalfa cell wall material contains more pectin than grasses [49]. This polysaccharide contains large amounts of galacturonic acid. Both protein and galacturonic acid are good buffering agents. In light of the differences in cellulose degradability and buffering, further research is needed to better understand the influence of legume plant structure and composition on sugar recovery.

\subsection{Recovery of non-glucan sugars}

Trends observed for recovery of non-glucose sugars were very different than those observed for glucose. Conversion efficiency of these sugars did not appear to be influenced by maturity. The significant factors that determined the yield of non-glucose sugars were their concentration in the various biomass samples and pretreatment temperature. The alfalfa stem samples had much lower amounts of nonglucose sugars than the grasses, and yields of these sugars were consequently much lower. Yield of non-glucose sugars increased with greater maturity because the concentrations of these sugars also increased with maturity in all biomass samples. This is the first study to directly evaluate the influence of maturity on recovery of nonglucose sugars by dilute-acid hydrolysis.

Whether the biomass samples were treated at 121 or $150{ }^{\circ} \mathrm{C}$ had a significant influence on non-glucose sugar yields. Yields were lower at the higher temperature, which we suspected was caused by thermal degradation of the sugars at the higher temperature. In fact, this reduction in yields at the higher temperature was highly correlated with fructose concentration, the most acid labile of the sugars. Usually the optimal temperature for glucose yield from cellulose is too high for maximum recovery of xylan sugars [50]. This trend was exasperated because of the presence of non-cell wall sugars, in particular fructose [51], in the biomass samples evaluated in the current study. The sensitivity of fructose to degradation at higher pretreatment temperatures had particular relevance to reed canarygrass $\left(\mathrm{C}_{3}\right.$ grass $)$ because it had twice the fructose content of switchgrass $\left(\mathrm{C}_{4}\right.$ grass $)$. Other cool-season $\left(\mathrm{C}_{3}\right)$ grasses also often accumulate fructose in the form of fructans [25] and would presumably be similarly sensitive to degradation of fructose by high temperature dilute-acid pretreatment.

The effectiveness of pretreatment results reported here are comparable to those reported in other studies. Torget and colleagues reported on dilute-acid pretreatment of the grasses: switchgrass and weeping lovegrass (Eragrotis curvula) [46,47]. The reported yields for switchgrass $(80-90 \%)$ were similar to those reported here $(73-86 \%)$; albeit their yields did not account for glucose from soluble carbohydrates. Substantially lower yields (30-40\%) were reported for herbaceous legume sericea lespedeza (Lespedeza cuneata). However, the recalcitrance of the legume cellulose was somewhat overcome by increasing the pretreatment temperature to $180^{\circ} \mathrm{C}$.

\section{Conclusion}

For the three biomass species examined, yields of potentially fermentable sugars were a result of both variation in carbohydrate composition and efficiency of release by the dilute acid/enzymatic saccharification conversion process. Soluble sugar contents were significant, especially for the younger crops, and extraction of these sugars prior to pretreatment might prove beneficial. Overall carbohydrate contents increased with plant maturity; however, extracting the glucans becomes more challenging with increased plant maturity. Therefore, it is likely that pretreatment severity will need to be increased to compensate for maturity, which may lower the yields of hemicellulose sugars. Yield of glucose was greatest from the switchgrass and least for alfalfa. The reduced glucose yield from alfalfa was due to its lower efficiency of cellulose hydrolysis. However, readers are cautioned that the preceding observations should be viewed as only preliminary and that definitive conclusions on these topics will require analysis of larger sample sets of each species and maturity stages that have been grown across a range of environmental conditions.

\section{Acknowledgment}

The authors thank Ms. Patricia O'Bryan, Mr. Richard Jeo, and Mr. Steven Masterson for their excellent technical assistance. The authors also thank Dr. Paul Weimer for measuring organic acids and helpful discussions.

\section{References}

[1] McKendry P. Energy production from biomass (Part 2): conversion technologies. Bioresource Technology 2002;83:47-54.

[2] Hamelinck CN, van Hooijdonk G, Faaij APC. Ethanol from lignocellulosic biomass: techno-economic performance in short-, middle-, and long-term. Biomass \& Bioenergy 2005;28:384-410.

[3] McKendry P. Energy production from biomass (Part 1): overview of biomass. Bioresource Technology 2002;83:37-46.

[4] McLaughlin SB, Walsh ME. Evaluating the environmental consequences of producing herbaceous crops for bioenergy. Biomass \& Bioenergy 1998;14:317-24.

[5] McLaughlin SB, De La Torre Ugarte Jr DG, Garten CT, Lynd LR, Sanderson MA, Tolbert VR, et al. High-value renewable energy from prairie grasses. Environmental Science \& Technology 2002;36: 2122-9.

[6] Frank AB, Berdahl JD, Hanson JD, Liebig MA, Johnson HA. Biomass and carbon partitioning in switchgrass. Crop Science 2004;44:1391-6.

[7] Liebig MA, Johnson HA, Hanson JD, Frank AB. Soil carbon under switchgrass stands and cultivated cropland. Biomass \& Bioenergy 2005;28:347-54.

[8] Lemus R, Lai R. Bioenergy crops and carbon sequestration. Critical Reviews in Plant Sciences 2005;24:1-21.

[9] Roth AM, Sample DW, Ribic CA, Paine L, Understander DJ, Bartelt GA. Grassland bird response to harvesting switchgrass as a biomass energy crop. Biomass \& Bioenergy 2005;28:490-8.

[10] McLaughlin SM, Bouton J, Bransby D, Conger B, Ocumpaugh W, Parrish D, et al. Developing switchgrass as a bioenergy crop. In: 
Janick J, editor. Perspectives on new crops and new uses. Alexandra, VA: ASHS Press; 1999. p. 282-99.

[11] Vogel KP. Energy production from forages (or American agriculture - back to the future). Journal of Soil and Water Conservation 1996;51:137-9.

[12] Lewandowski I, Scurlock JMO, Lindvall E, Christou M. The development and current status of perennial rhizomatous grasses as energy crops in the U.S. and Europe. Biomass \& Bioenergy 2003;25:335-61.

[13] Jung HG, DeLong MM, Oelke EA, Martin NP, Barnes DK. Alfalfa hay as a biomass energy crop for electricity generation. In: Proceeding of the 34th North American alfalfa improvement conference, Guelph, Ont., Canada, 1994. p. 50.

[14] Martin GC, Clapp CE, Larsen WF. Effects of municipal wastewater effluent and cutting management on persistence and yield of eight perennial forages. Agronomy Journal 1979;71:650-8.

[15] DiCostanzo A, Zehnder CM, Akayezu JM, Jorgensen MA, Cassady JM, Allen DM, et al. Use of alfalfa leaf meal in ruminant diets. In: Proceedings of the 60th Minnesota nutr. conference, Bloomington, MN, 1999, p. 64-75.

[16] Sun Y, Cheng J. Hydrolysis of lignocellulosic materials for ethanol production: a review. Bioresource Technology 2002;83:1-11.

[17] Wilson JR. Organization of forage plant tissues. In: Jung HG, Buxton DR, Hatfield RD, Ralph J, editors. Forage cell wall structure and digestibility. Madison, WI, USA: ASA-CSSA-SSSA; 1993. p. 1-32.

[18] Buxton DR, Casler MD. Environmental and genetic effects on cell wall composition and digestibility. In: Jung HG, Buxton DR, Hatfield RD, Ralph J, editors. Forage cell wall structure and digestibility, ASA-CSSA-SSSA; 1993. p. 685-714.

[19] Kalu BA, Fick GW. Morphological stage of development as a predictor of alfalfa herbage quality. Crop Science 1983;23:1167-72.

[20] Moore KJ, Moser LE, Vogel KP, Waller SS, Johnson BE, Pedersen JF. Describing and quantifying growth stages of perennial grasses. Agronomy Journal 1991;83:1073-7.

[21] Padmore JM. Protein (crude) in animal feed Dumas method. Method. In: Herlich K, editor. Official methods of analysis of association of official analytical chemists, 15th ed. Arlington, VA; 1990.

[22] Padmore JM. Fat (crude) or ether extract in animal feed. Method 920.39. In: Herlich K, editor. Official methods of analysis of association of official analytical chemists, 15th ed. Arlington, VA; 1990.

[23] Weimer PJ, Shi Y, Odt CL. A segmented gas/liquid delivery system for continuous culture of microorganisms on solid substrates, and its use for growth of Ruminococcus flavefaciens on cellulose. Applied Microbiology and Biotechnology 1991;36:178-83.

[24] Knudsen DR, Clark RB, Denning JL, Pier PS. Plant analysis of trace elements by X-ray. Journal of Plant Nutrition 1981;3:61-75.

[25] Smith D. The nonstructural carbohydrates. In: Butler GW, Bailey RW, editors. Chemistry and biochemistry of herbage, vol. 1. New York, NY: Academic Press; 1973. p. 105-55.

[26] Boratynski J. Colorimetric method for the determination of ketoses using phenol-acetone-boric acid reagent (PABR). Analytical Biochemistry 1984;137:528-32.

[27] Theander O, Aman P, Westerlund E, Andersson R, Pettersson D. Total dietary fiber determined as neutral sugar residues, uronic acid residues, and Klason lignin (The Uppsala Method): collaborative study. Journal of AOAC International 1995;78:1030-44.

[28] Ahmed AER, Labavitch JM. A simplified method for accurate determination of cell wall uronide content. Journal of Food Biochemistry 1977;1:361-5.

[29] Van Soest PJ, Robertson JB, Lewis BA. Methods for dietary fiber, neutral detergent fiber, and nonstarch polysaccharides in relation to animal nutrition. Journal of Dairy Science 1991;74:3583-97.

[30] Vogel KP, Pedersen JF, Masterson SD, Toy JJ. Evaluation of a filter bag system for NDF, ADF, and IVDMD forage analysis. Crop Science 1999;39:276-9.
[31] Dien BS, Nagle N, Hicks KB, Singh V, Moreau RA, Tucker MP, Nichols NN, Johnston DB, Cotta MA, Nguyen Q, Bothast RJ. Fermentation of "Quick Fiber" produced from a modified cornmilling process into ethanol and recovery of corn fiber. Applied Biochemistry and Biotechnology 2004;113-116:937-49.

[32] Brown L, Torget R. Enzymatic saccharification of lignocellulosic biomass; LAP-009. NREL Analytical Procedure. National Renewable Energy Laboratory, Golden, CO.

[33] Ghose TK. Measurement of cellulase activities. Pure and Applied Chemistry 1984;59:257-68.

[34] Albersheim P, Nevins DJ, English PD, Karr A. A method for the analysis of sugars in plant cell-wall polysaccharides by gas-liquid chromatography. Carbohydrate Research 1967;5-3:340-5.

[35] Dien BS, Cotta MA, Jeffries TW. Bacteria engineered for fuel ethanol production: current status. Applied Microbiology and Biotechnology 2003;63:258-66.

[36] Jung HG, Deetz DA. Cell wall lignification and degradability. In: Jung HG, Buxton DR, Hatfield RD, Ralph J, editors. Forage cell wall structure and digestibility. Madison, WI, USA: ASA-CSSASSSA; 1993. p. 315-46.

[37] Jung HG, Mertens DR, Payne AJ. Correlation of acid detergent lignin and Klason lignin with digestibility of forage dry matter and neutral detergent fiber. Journal of Dairy Science 1997;80:1622-8.

[38] Jung H- JG, Varel VH, Weimer PJ, Ralph J. Accuracy of Klason lignin and acid detergent lignin methods as assessed by bomb calorimetry. Journal of Agricultural and Food Chemistry 1999;47: 2005-8.

[39] Theander O, Westerlund E. Quantitative analysis of cell wall components. In: Jung HG, Buxton DR, Hatfield RD, Ralph J, editors. Forage cell wall structure and digestibility. Madison, WI, USA: ASA-CSSA-SSSA; 1993. p. 33-71.

[40] Morrison IM. Hemicellulosic contamination of acid detergent residues and their replacement by cellulose residues in cell wall analysis. Journal of the Science of Food and Agriculture 1980;31: 639-45.

[41] Jung HG, Lamb JFS. Prediction of cell wall polysaccharide and lignin concentrations of alfalfa stems from detergent fiber analysis. Biomass \& Bioenergy 2004;27:365-73.

[42] Vogel KP, Jung H-JG. Genetic modification of herbaceous plants for feed and fuel. Critical Reviews in Plant Sciences 2001;20:15-49.

[43] Chang VS, Holtzapple MT. Fundamental factors affecting biomass enzymatic reactivity. Applied Biochemistry and Biotechnology 2000;84-6:5-37.

[44] Converse AO. Substrate factors limiting enzymatic hydrolysis. In: Saddler JN, editor. Bioconversion of forest and agricultural plant residues. Wallingford, UK: CAB International; 1993. p. 93-106.

[45] Hsu T-A. Pretreatment of biomass. In: Wyman CE, editor. Handbook on ethanol: production and utilization. Washington, DC: Taylor and Francis; 1996. p. 179-212.

[46] Torget R, Werdene P, Himmel M, Grohmann K. Dilute acid pretreatment of short rotation woody and herbaceous crops. Applied Biochemistry and Biotechnology 1990;24-25:115-26.

[47] Torget R, Himmel M, Grohmann K. Dilute-acid pretreatment of two short-rotation herbaceous crops: scientific note. Applied Biochemistry and Biotechnology 1992;34-35:115-23.

[48] Engels FM, Jung HG. Alfalfa stem tissues: cell-wall development and lignification. Annals of Botany 1998;82:561-8.

[49] Moore KJ, Hatfield RD. Carbohydrates and forage quality. In: Fahey Jr GC, Collins M, Mertens DR, Moser LE, editors. Forage quality, evaluation, and utilization. Madison, WI, USA: ASA-CSSASSSA; 1994. p. 229-80.

[50] Dien BS, Iten LB, Skory CD. Converting herbaceous energy crops to bioethanol; a review with emphasis on pretreatment processes. In: Hou CT, editor. Handbook of industrial biocatalysis, Chapter 23. Boca Raton, FL: Taylor and Francis; 2005. p. 1-11.

[51] Kuster BFM, Temmink HMG. The influence of $\mathrm{pH}$ and weak-acid anions on the dehydration of D-fructose. Carbohydrate Research 1977;54:185-91. 